\title{
MONITORING NYERI DENGAN KAMERA TERMAL PADA PASIEN CEDERA KEPALA DENGAN TERAPI ES BATU DI RSUP DR. WAHIDIN SUDIROHUSODO MAKASSAR
}

\author{
Suhatman A. Hakim ${ }^{1,2 \bowtie}$, Elly L. Sjattar ${ }^{1}$, Muh. Nasrum Massi ${ }^{3}$ \\ ${ }^{1}$ Program Magister Ilmu Keperawatan Universitas Hasanuddin Makassar \\ ${ }^{2}$ RSUP Dr. Wahidin Sudirohusodo Makassar \\ ${ }^{3}$ Departemen Mikrobiologi Fakultas Kedokteran Universitas Hasanuddin Makassar
}

\section{ARTICLE INFO \\ Article history}

Submitted : 2019-07-28

Revised : 2020-06-29

Accepted : 2020-07-06

Keywords:
Cube Ice Therapy
Pain
Thermal Camera
VRS

\section{Kata Kunci:}

Terapi Es Batu

Nyeri

Kamera Termal

VRS

\begin{abstract}
Headache is the most common somatic disorder in patients after head injury (29-54\%). The use of acupuncture points has been used, especially in China in treating various health problems such as headaches. This study aims to determine the effect of ice cube therapy at Feng Fu GV 16 point on decreasing pain in patients with Head Injury who have Post Traumatic Headache in RSUP DR Wahidin Sudirohusodo Makassar with thermal camera monitoring indicators and VRS. This study uses the quasy experiment method. Sampling with accidental sampling with a total sample of 30 people (15 controls and 15 experimental groups). The experimental group was given analgesic + ice therapy at GV Feng Fu 16 point while the control group was only given analgesic. Data was tested by the Independent $T$ Test statistical test with a confidence level of 95\%. All data were analyzed using the SPSS version 21.0 program (SPSS, Inc. Chicago, IL). Mean changes in VRS intervention group $(1.20 \pm 0.56)$ and control group $(0.80 \pm$ 0.56 ) and mean changes in facial temperature with thermal camera monitoring of the intervention group $(1.48 \pm 5,09)$ and the control group $(0.93 \pm 1.71)$. There was no difference in changes in VRS (p: 0.061) and Face Scale (p: 0.698) between the intervention group and the control group. Giving ice cube at Feng Fu GV 16 point is not significant to reduction of pain in Head Injury patients who experience Post Traumatic Headache with VRS indicators and facial temperature with thermal camera monitoring compared to control group. By that, for practitioners in hospitals to be able to increase knowledge related to ice cube therapy at Feng Fu GV 16 point in reducing pain.

Sakit kepala adalah kelainan somatik paling umum pada pasien setelah cedera kepala (29-54\%). Penggunaan titik akupunktur telah digunakan, terutama di China dalam mengobati berbagai masalah kesehatan seperti sakit kepala. Penelitian ini bertujuan untuk mengetahui pengaruh terapi es batu pada titik Feng Fu GV 16 terhadap penurunan nyeri pada pasien dengan Cedera Kepala yang menderita Post Traumatic Headache di RSUP DR Wahidin Sudirohusodo Makassar dengan indikator pemantauan kamera termal dan VRS. Penelitian ini menggunakan metode Quasi Eksperiment. Pengambilan sampel dengan accidental sampling dengan total sampel 30 orang (15 kontrol dan 15 kelompok eksperimen). Kelompok eksperimen diberi terapi analgesik + es pada titik GV Feng Fu 16 sedangkan kelompok kontrol hanya diberi analgesik. Data diuji dengan uji statistik Independent T Test dengan tingkat kepercayaan 95\%. Semua data dianalisis menggunakan program SPSS versi 21.0 (SPSS, Inc. Chicago, IL). Perubahan rata-rata pada kelompok intervensi VRS $(1,20 \pm 0,56)$ dan kelompok kontrol $(0,80 \pm 0,56)$ dan perubahan rata-rata pada suhu wajah dengan pemantauan kamera termal dari kelompok intervensi $(1,48 \pm 5,09)$ dan kelompok kontrol $(0,93 \pm 1,71)$. Tidak ada perbedaan dalam perubahan VRS (p: 0,061) dan Skala Wajah (p: 0,698) antara kelompok intervensi dan kelompok kontrol. Pemberian es batu pada titik Feng Fu GV 16 tidak signifikan terhadap pengurangan nyeri pada pasien Cidera Kepala yang mengalami Sakit Kepala Pasca Trauma dengan indikator VRS dan suhu wajah dengan pemantauan kamera termal dibandingkan dengan kelompok kontrol. Oleh karena itu, bagi para praktisi di rumah sakit untuk dapat meningkatkan pengetahuan terkait dengan terapi es batu di titik Feng Fu GV 16 dalam mengurangi rasa sakit.
\end{abstract}

\section{Corresponding Author:}

Suhatman A. Hakim

Program Magister Ilmu Keperawatan Universitas Hasanuddin Makassar

Telp. 085299223789

Email: $\underline{\text { mohattariqh@gmail.com }}$ 


\section{PENDAHULUAN}

Cedera Kepala (CK) merupakan jenis trauma terbanyak yang masuk ke unit Gawat Darurat (Zaloshanja, Miller, Langlois, \& Selassi,2008). Diperkirakan jumlah kasus cedera kepala di seluruh dunia berkisar 50\% dari seluruh kasus cedera yang menyebabkan kematian (Harvey S. Levin, David H.K Shum, Raymand C.K.Chan, 2014). Sejumlah gejala sisa yang dapat ditemui dalam waktu lama pada pasien cedera kepala seperti nyeri kepala, pusing, kejang dan gangguan tidur (Trevena \& Cameron, 2011). Nyeri kepala posttraumatic (PTH) merupakan gangguan somatic paling umum pada pasien pasca cedera kepala (2954\%) (Trevena \& Cameron, 2011).

Telah banyak terapi yang dilakukan untuk mengatasi PTH, umumnya nyeri kepala di atasi dengan terapi farmakologik dengan pemberian analgetik yang sesuai dengan jenis nyeri kepala itu sendiri, akan tetapi penggunaan analgetik yang lama tentunya juga akan mempengaruhi pasien itu sendiri (Huang et al., 2013). Terapi komplementer merupakan terapi pilihan yang lain yang juga merupakan terapi alternatif non farmakologis (Kjeldgaard et al., 2014).

Perkembangan terapi komplementer cukup berkembang salah satunya teknik pengobatan menggunakan titik tertentu di tubuh nyang disebut Accupoint (Frandsen., 2016). Penggunaan titik akupunktur digunakan terutama di Cina dalam mengobati berbagai kondisi masalah kesehatan seperti nyeri kepala, beberapa titik akupoint dapat digunakan untuk penyembuhan, di antaranya adalah titik point FengFu atau GV 16 (Zhao JY, Liu Y, Xi SH, 2015).

Saat ini, tingkat keparahan nyeri dinilai oleh banyak metode subjektif. Beberapa metode bergantung pada pasien seperti Verbal Rating Scale (VRS). Pemantauan nyeri yang efektif sangat penting untuk meningkatkan kualitas perawatan. Penelitian sebelumnya menemukan bahwa kamera termal dapat digunakan untuk memonitoring secara objektif nyeri (Erel \& Özkan, 2017). Untuk itu, dalam memonitor nyeri dalam penelitian ini, peneliti menggunakan dua indikator yakni indikator subjektif berupa VRS dan indikator objektif berupa kamera termal.

\section{METODE PENELITIAN Jenis Penelitian}

Penelitian ini menggunakan metode quasy experiment. Pengambilan sampel dengan accidental sampling dengan jumlah sampel sebanyak 30 orang (15 kontrol dan 15 kelompok eksperimen). Peneliti merekrut pasien cedera kepala di ruang Lontara 3 Bedah Saraf RSUP Dr. Wahidin Sudirohusodo Makassar sesuai dengan kriteria inklusi dan eksklusi, selanjutnya peneliti membagi responden pada kelompok intervensi dan kelompok kontrol secara acak.

Kelompok eksperimen diberikan analgetik + es dengan ukuran $2 \times 2 \mathrm{~cm}$ pada titik Feng Fu GV 16 yang terletak 1 jari di atas batas rambut belakang sedangkan kelompok kontrol hanya diberikan analgetik.

\section{Instrumen Penelitian}

Pengukuran nyeri secara obyektif dilakukan dengan menggunakan Alat Kamera Infra Merah FLIRR ONE for IOS dengan mengukur perubahan suhu pada beberapa titik yang telah ditentukan, yaitu titik Fullface Measurement (FFM), Horisontal of Line (HOL), High Point (HP), Nasolabial Sulcus Right (NSL-1) dan Nasolabial Sulcus Left (NSL-2). Instrumen penilaian nyeri dalam penelitian ini juga menggunakan Verbal Rating Scale (VRS) dalam mengukur nyeri kepala (headache) sebelum dan setelah diberikan intervensi.

\section{Pengumpulan Data}

Peneliti merekrut pasien cedera kepala di ruang Lontara 3 Bedah Saraf RSUP Dr. Wahidin Sudirohusodo Makassar sesuai dengan kriteria inklusi dan eksklusi, selanjutnya peneliti membagi responden pada kelompok intervensi dan kelompok kontrol secara acak. Berikut ini prosedur pengumpulan data pada kedua kelompok :

\section{Kelompok intervensi}

a. Peneliti menjelaskan tujuan penelitian dan prosedur intervensi sesuai dengan lembar permintaan menjadi responden

b. Peneliti mempersilahkan responden untuk mengisi dan menandatangani informed consent bagi responden yang bersedia untuk mengikuti dalam penelitian

c. Peneliti mengukur nyeri kepala menggunakan VRS (Verbal Rating Scale) dan melakukan pengambilan gambar wajah dengan kamera Inframerah FLIRR ONE for IOS sebelum diberikan intervensi. 
d. Peneliti mengatur lingkungan dan posisi responden senyaman mungkin

e. Peneliti memberikan relaksasi dengan memijat tengkuk dan bahu responden dengan menggunakan jari dan telapak tangan sebanyak 5 (lima) kali

f. Peneliti menstimulasi titik akupresur Feng Fu GV 16 menggunakan es batu selama 10 menit.

g. Peneliti mengukur kembali nyeri kepala menggunakan VRS (Verbal Rating Scale) dan melakukan pengambilan gambar wajah dengan kamera Inframerah FLIRR ONE for IOS setelah diberikan intervensi.

\section{Kelompok Kontrol}

a. Peneliti menjelaskan tujuan penelitian dan prosedur kerja sesuai dengan lembar permintaan menjadi responden

b. Peneliti mempersilahkan respon den untuk mengisi dan menandatangani informed consent bagi responden yang bersedia untuk mengikuti dalam penelitian

c. Peneliti mengukur nyeri kepala menggunakan VRS (Verbal Rating Scale) dan melakukan pengambilan gambar wajah dengan kamera Inframerah FLIRR ONE for IOS 10-15 detik sebelum jadwal pemberian analgetik.

d. Peneliti membiarkan responden hanya menerima analgetik sesuai dosis dari SPO rumah sakit, pengukuran nyeri berikutnya dilakukan setelah efek analgetik mulai habis, menggunakan VRS (Verbal Rating Scale) dan melakukan pengambilan gambar wajah dengan kamera Inframerah FLIRR ONE for IOS 10-15 detik setelah efek analgetik habis ( 8 Jam setelah injeksi).

\section{Etik Penelitian}

Penelitian ini telah disetujui oleh Komisi Etik dan Penelitian Fakultas Kedokteran Universitas Hasanuddin (193/H484531/PP36-KOMETIK/ 2016).

\section{Analisis}

Data diuji dengan uji statistik Independent $T$ Test dengan tingkat kepercayaan 95\%. Semua data dianalisis dengan program SPSS versi 21,0 (SPSS, Inc Chicago, IL).

\section{HASIL PENELITIAN}

Karakterisitik responden didapat kan bahwa tidak ada perbedaan jenis kelamin $(\mathrm{p}=0,699)$, pendidikan $(\mathrm{p}=0,276)$, dan status pernikahan $\quad(p=0,130)$ antara kelompok intervensi dan kelompok kontrol sehingga data dapat dikatakan homogen (Tabel 1).

Umur dan tanda-tanda vital respon den didapatkan bahwa tidak ada perbedaan umur $(\mathrm{p}=0,899)$, tekanan darah systole $(\mathrm{p}=0,776)$, tekanan darah dyastole $(\mathrm{p}=0,529)$, nadi $(\mathrm{p}=0,335)$, dan pernapasan $(\mathrm{p}=0,724)$ antara kelompok intervensi dan kelompok kontrol sehingga data dapat dikatakan homogen terkait dengan umur dan tanda-tanda vital (Tabel 2). Rata-rata VRS pada saat pre test pada kelompok intervensi $(2,87 \pm 0,51)$ dan kelompok kontrol $(2,87 \pm 0,51)$, rata-rata VRS pada saat post test pada kelompok intervensi $(1,67 \pm 0,61)$ dan kelompok kontrol $(2,07 \pm 0,59)$, adapun perubahan VRS kelompok intervensi $(1,20 \pm 0,56)$ dan kelompok kontrol $(0,80 \pm 0,56)$ (Tabel 3).

Rata-rata suhu wajah responden dengan menggunakan kamera termal didapatkan ratarata perubahan suhu wajah area $F F M$ kelompok intervensi $(1,48 \pm 5,09)$ dan kelompok kontrol $(0,93 \pm 1,71)$, rata-rata perubahan suhu wajah area $H P$ kelompok intervensi $(1,72 \pm 4,54)$ dan kelompok kontrol $(1,03 \pm 1,20)$, rata-rata perubahan suhu wajah area $H O L$ kelompok intervensi $(1,84 \pm 4,78)$ dan kelompok kontrol $(0,96 \pm 1,46)$, rata-rata perubahan suhu wajah area NSL-1 kelompok intervensi $(1,64 \pm 4,74)$ dan kelompok kontrol $(0,92 \pm 1,50)$, rata-rata perubahan suhu wajah area $N S L-2$ kelompok intervensi $(1,64 \pm 4,86)$ dan kelompok kontrol $(0,75 \pm 1,45)$ (Tabel 4).

Efek terapi es batu pada titik Feng Fu GV 16 terhadap penurunan nyeri dengan indikator VRS menunjukkan bahwa tidak ada efek signifikan es batu pada titik Feng Fu GV 16 terhadap penurunan nyeri pada pasien Cedera Kepala yang mengalami Post Traumatic Headache di RSUP DR Wahidin Sudirohusodo Makassar dengan indikator VRS $(\mathrm{p}=0,061)$ (Tabel 5). Efek terapi es batu pada titik Feng Fu GV 16 terhadap penurunan nyeri dengan indikator monitoring kamera termal pada wajah menunjukkan bahwa tidak ada efek signifikan es batu pada titik Feng Fu GV 16 terhadap penurunan nyeri pada pasien Cedera Kepala yang mengalami Post Traumatic Headache di RSUP DR Wahidin Sudirohusodo Makassar dengan indikator monitoring kamera termal suhu wajah area FFM $(\mathrm{p}=0,698)$, area HP $(\mathrm{p}=0,583)$, area HOL $(\mathrm{p}=0,509)$, area NSL-1 
$(\mathrm{p}=0,583)$, area NSL-2 $(\mathrm{p}=0,505)$ dan VRS $\quad(\mathrm{p}=0,061)$ (Tabel 6).

Tabel 1. Karakteristik Responden berdasarkan Kelompok

\begin{tabular}{|c|c|c|c|c|c|}
\hline \multirow{3}{*}{ Variabel } & \multicolumn{4}{|c|}{ Kelompok } & \multirow{3}{*}{$\mathbf{p}$} \\
\hline & \multicolumn{2}{|c|}{ Intervensi } & \multicolumn{2}{|c|}{ Kontrol } & \\
\hline & n (15) & $\%$ & n (15) & $\%$ & \\
\hline \multicolumn{6}{|l|}{ Jenis Kelamin } \\
\hline Laki-laki & 9 & 60,0 & 11 & 73,3 & $0,699 *$ \\
\hline Perempuan & 6 & 40,0 & 4 & 26,7 & \\
\hline \multicolumn{6}{|l|}{ Pendidikan } \\
\hline SD & 1 & 6,7 & 0 & 0,0 & \\
\hline SMP & 4 & 26,7 & 1 & 6,7 & $0,276^{*}$ \\
\hline SMA & 7 & 46,6 & 8 & 53,3 & \\
\hline Perguruan Tinggi & 3 & 20,0 & 6 & 40,0 & \\
\hline \multicolumn{6}{|l|}{ Status Pernikahan } \\
\hline Menikah & 12 & 80,0 & 7 & 46,7 & $0,130 *$ \\
\hline Belum Menikah & 3 & 20,0 & 8 & 53,3 & \\
\hline
\end{tabular}

Tabel 2. Umur dan Tanda-Tanda Vital Responden berdasarkan Kelompok

\begin{tabular}{llccccc}
\hline Karakteristik & Kelompok & $\mathbf{n}$ & Mean \pm SD & Median & Min - Max & p \\
\hline \multirow{2}{*}{ Umur (tahun) } & Intervensi & 15 & $29,53 \pm 13,20$ & 26 & $17-56$ & \multirow{2}{*}{0,899} \\
& Kontrol & 15 & $29,00 \pm 9,22$ & 27 & $16-45$ & \\
Tekanan Darah & Intervensi & 15 & $120,6 \pm 8,0$ & 123 & $110-135$ & 0,776 \\
Systole & Kontrol & 15 & $121,5 \pm 8,53$ & 123 & $110-140$ & \\
Tekanan Darah & Intervensi & 15 & $70,73 \pm 5,23$ & 70 & $60-80$ & 0,529 \\
Dyastole & Kontrol & 15 & $71,80 \pm 3,84$ & 70 & $65-80$ & \\
\multirow{2}{*}{ Nadi } & Intervensi & 15 & $78,20 \pm 9,07$ & 80 & $58-88$ & 0,335 \\
& Kontrol & 15 & $80,87 \pm 5,33$ & 80 & $74-90$ & \\
Pernapasan & Intervensi & 15 & $21,60 \pm 2,02$ & 20 & $20-24$ & 0,724 \\
& Kontrol & 15 & $21,87 \pm 2,06$ & 20 & $20-24$ & \\
\hline
\end{tabular}

*Independent T Test, $p<0,05$ dinyatakan bermakna

Table 3. Rata-Rata Skala Nyeri Responden berdasarkan VRS

\begin{tabular}{ccccccccc}
\hline Verbal & \multicolumn{3}{c}{ Intervensi(n=15) } & \multicolumn{5}{c}{ Kontrol (n=15) } \\
\cline { 2 - 10 } Rating Scale & Mean \pm SD & Median & Min & Max & Mean \pm SD & Median & Min & Max \\
\hline Pre Test & $2,87 \pm 0,51$ & 3 & 2 & 4 & $2,87 \pm 0,51$ & 3 & 2 & 4 \\
Post Test & $1,67 \pm 0,61$ & 2 & 1 & 3 & $2,07 \pm 0,59$ & 2 & 1 & 3 \\
Perubahan & $1,20 \pm 0,56$ & 1 & 0 & 2 & $0,80 \pm 0,56$ & 1 & 0 & 2 \\
\hline
\end{tabular}

\section{PEMBAHASAN}

Hasil dari penelitian ini didapatkan bahwa tidak ada efek signifikan es batu pada titik Feng Fu GV 16 terhadap penurunan nyeri pada pasien Cedera Kepala yang mengalami Post Traumatic Headache di RSUP DR Wahidin Sudirohusodo Makassar dengan indikator VRS $(\mathrm{p}=0,061)$ dan monitoring 
kamera termal suhu wajah area FFM $(\mathrm{p}=0,698)$, area HP $(\mathrm{p}=0,583)$, area HOL $(\mathrm{p}=0,509)$, area NSL-1 $(\mathrm{p}=0,583)$, area NSL-2 $(\mathrm{p}=0,505)$ dan $\operatorname{VRS}(\mathrm{p}=0,061)$.

Meskipun secara statistik tidak bermakna secara signifikan, tetapi secara ratarata didapatkan bahwa penurunan skala nyeri dengan indikator VRS dan suhu wajah lebih tinggi pada kelompok intervensi dibandingkan dengan kelompok kontrol sehingga dapat disimpulkan ada kecenderungan efek es batu pada titik Feng Fu GV 16 terhadap penurunan nyeri pada pasien Cedera Kepala yang mengalami Post Traumatic Headache dengan indikator VRS dan monitoring kamera termal suhu wajah.

Tabel 4. Rata-Rata Skala Nyeri Responden berdasarkan Suhu Wajah dengan Menggunakan Kamera Termal

\begin{tabular}{llcccccccc}
\hline \multirow{2}{*}{$\begin{array}{c}\text { Suhu } \\
\text { Wajah }\end{array}$} & \multirow{3}{*}{ Variabel } & \multicolumn{3}{c}{ Intervensi(n=15) } & \multicolumn{5}{c}{ Kontrol $(\mathbf{n = 1 5})$} \\
\cline { 3 - 10 } Area & Pre Test & $34,06 \pm 3,23$ & 33,6 & 29,7 & 39,1 & $34,36 \pm 2,59$ & 33,6 & 31,4 & 41,0 \\
FFM & Post Test & $32,58 \pm 5,65$ & 32,6 & 23,2 & 41,7 & $33,42 \pm 2,04$ & 33,2 & 29,7 & 37,6 \\
& Perubahan & $1,48 \pm 5,09$ & 2,0 & -11 & 9,5 & $0,93 \pm 1,71$ & 0,6 & $-1,5$ & 6,3 \\
Area & Pre Test & $34,46 \pm 2,97$ & 33,9 & 29,3 & 38,8 & $34,59 \pm 2,37$ & 33,9 & 31,6 & 40,0 \\
HP & Post Test & $32,74 \pm 5,58$ & 33,2 & 23,4 & 41,8 & $33,56 \pm 2,22$ & 33,2 & 29,3 & 37,4 \\
& Perubahan & $1,72 \pm 4,54$ & 2,4 & $-6,9$ & 10,5 & $1,03 \pm 1,20$ & 0,7 & $-0,6$ & 4,4 \\
Area & Pre Test & $34,38 \pm 2,94$ & 33,5 & 29,8 & 39,5 & $34,59 \pm 2,32$ & 33,5 & 31,5 & 40,1 \\
HOL & Post Test & $32,54 \pm 5,79$ & 33,0 & 22,3 & 42,0 & $33,62 \pm 2,01$ & 33,2 & 30,3 & 37,7 \\
& Perubahan & $1,84 \pm 4,78$ & 2,0 & $-6,6$ & 11,2 & $0,96 \pm 1,46$ & 0,7 & $-1,2$ & 5,4 \\
Area & Pre Test & $34,41 \pm 2,99$ & 34,4 & 29,7 & 38,7 & $34,31 \pm 2,36$ & 33,8 & 31,2 & 39,5 \\
NSL-1 & Post Test & $32,77 \pm 5,53$ & 32,5 & 23,5 & 42,2 & $33,39 \pm 2,17$ & 32,7 & 29,7 & 37,3 \\
& Perubahan & $1,64 \pm 4,74$ & 1,1 & $-6,0$ & 10,9 & $0,92 \pm 1,50$ & 1,1 & $-1,2$ & 4,9 \\
Area & Pre Test & $34,12 \pm 3,04$ & 33,6 & 29,6 & 39,6 & $34,05 \pm 2,34$ & 33,5 & 30,5 & 39,4 \\
NSL-2 & Post Test & $32,48 \pm 5,75$ & 32,0 & 22,5 & 42,5 & $33,30 \pm 2,12$ & 32,8 & 29,6 & 37,3 \\
& Perubahan & $1,64 \pm 4,86$ & 1,0 & $-5,9$ & 11,0 & $0,75 \pm 1,45$ & 0,9 & $-1,5$ & 4,9 \\
\hline
\end{tabular}

Untuk perubahan, (+) Menurun (-) Meningkat

Tabel 5. Efek Terapi Es Batu pada Titik Feng Fu GV 16 terhadap Penurunan Nyeri pada Pasien Cedera Kepala yang Mengalami Post Traumatic Headache di RSUP DR Wahidin Sudirohusodo Makassar dengan Indikator VRS

\begin{tabular}{|c|c|c|c|c|c|c|}
\hline \multirow{3}{*}{ Kelompok } & \multirow{3}{*}{$\mathbf{n}$} & \multicolumn{4}{|c|}{ Penurunan Verbal Rating Scale } & \multirow{3}{*}{$\mathbf{p}$} \\
\hline & & \multirow{2}{*}{ Mean \pm SD } & \multirow{2}{*}{$\begin{array}{c}\text { Mean Difference } \\
\pm \text { SD }\end{array}$} & \multicolumn{2}{|c|}{ CI $95 \%$} & \\
\hline & & & & Lower & Upper & \\
\hline $\begin{array}{l}\text { Intervensi } \\
\text { Kontrol }\end{array}$ & $\begin{array}{l}15 \\
15\end{array}$ & $\begin{array}{l}1,20 \pm 0,56 \\
0,80 \pm 0,56\end{array}$ & $0,40 \pm 0,20$ & $-0,01$ & 0,81 & 0,061 \\
\hline
\end{tabular}

* Independent T Test, $p<0,05$ dinyatakan bermakna

Hasil penelitian ini sejalan dengan beberapa penelitian sebelumnya yang dilakukan dengan membandingkan akupresur pada titik poin aktif secara rotari pada $20-25$ siklus per menit selama 30 detik pada setiap titik diberikan pada GB 21, B10, LI 4, GV 16, SI 14, dan SI 15 berturut-turut sedangkan kelompok yang satu diberikan TENS pada nyeri leher dengan hasil bahwa akupresur dapat menunjukkan efek yang lebih baik dalam 
menurunkan nyeri leher daripada TENS pada minggu ke 6 setelah terapi yaitu akupresur dapat menyeimbangkan energi tubuh, mengurangi ketegangan otot, mening katkan sirkulasi dan mendorong relaksasi yang dalam (Khan et al., 2017).

Tabel 6. Efek Terapi Es Batu pada Titik Feng Fu GV 16 terhadap Penurunan Nyeri pada Pasien Cedera Kepala yang Mengalami Post Traumatic Headache di RSUP DR. Wahidin Sudirohusodo Makassar dengan Indikator Monitoring Kamera Termal pada Suhu Wajah

\begin{tabular}{|c|c|c|c|c|c|c|c|}
\hline \multirow{3}{*}{ Area } & \multirow{3}{*}{ Kelompok } & \multirow{3}{*}{$\mathbf{n}$} & \multicolumn{4}{|c|}{$\begin{array}{c}\text { Penurunan Suhu Wajah dengan Monitoring } \\
\text { Kamera Termal }\end{array}$} & \multirow{3}{*}{ p } \\
\hline & & & \multirow{2}{*}{$\operatorname{Mean} \pm$ SD } & \multirow{2}{*}{$\begin{array}{c}\text { Mean Difference } \\
\pm \text { SD }\end{array}$} & \multicolumn{2}{|c|}{ CI $95 \%$} & \\
\hline & & & & & Lower & Upper & \\
\hline \multirow{2}{*}{ FFM } & Intervensi & 15 & $1,48 \pm 5,09$ & \multirow{2}{*}{$0,54 \pm 1,38$} & \multirow{2}{*}{$-2,29$} & \multirow{2}{*}{3,38} & \multirow{2}{*}{0,698} \\
\hline & Kontrol & 15 & $0,93 \pm 1,71$ & & & & \\
\hline HP & Intervensi & 15 & $1,72 \pm 4,54$ & \multirow{2}{*}{$0,68 \pm 1,21$} & \multirow{2}{*}{$-1,89$} & \multirow{2}{*}{3,25} & \multirow{2}{*}{0,583} \\
\hline \multirow{2}{*}{ HOL } & $\begin{array}{l}\text { Kontrol } \\
\text { Intervensi }\end{array}$ & $\begin{array}{l}15 \\
15\end{array}$ & $\begin{array}{l}1,03 \pm 1,20 \\
184+478\end{array}$ & & & & \\
\hline & Kontrol & 15 & $0,96 \pm 1,46$ & $0,87 \pm 1,29$ & $-1,86$ & 3,60 & 0,509 \\
\hline \multirow{2}{*}{ NSL-1 } & Intervensi & 15 & $1,64 \pm 4,74$ & \multirow{2}{*}{$0,72 \pm 1,28$} & \multirow{2}{*}{$-1,99$} & \multirow{2}{*}{2,11} & \multirow{2}{*}{0,583} \\
\hline & Kontrol & 15 & $0,92 \pm 1,50$ & & & & \\
\hline \multirow[t]{2}{*}{ NSL-2 } & Intervensi & 15 & $1,64 \pm 4,86$ & \multirow[t]{2}{*}{$0,89 \pm 1,31$} & \multirow[t]{2}{*}{$-1,88$} & \multirow[t]{2}{*}{3,66} & \multirow[t]{2}{*}{0,505} \\
\hline & Kontrol & 15 & $0,75 \pm 1,45$ & & & & \\
\hline
\end{tabular}

* Independent T Test, $p<0,05$ dinyatakan bermakna

JaeWoo Song et.al (2016), melakukan penelitian acak terkendali terkait manfaat terapi es batu dalam mengurangi nyeri saat dilakukan lokal anestesi pada 50 orang sampel yang terdiri dari dua grup dengan hasil bahwa terdapat penurunan nyeri yang signifikan $(\mathrm{p}=<0.001)$ pada kelompok perlakuan dibanding kelompok kontrol. Demikian pula Adel Alsantali (2018) yang melakukan Penelitian prospektif terhadap 23 pasien yang menjalani injeksi Botox pada telapak tangan, mendapatkan hasil yang signifikan $(\mathrm{p}<0.05)$ terhadap penurunan nyeri dengan melakukan kompres es dibanding dengan menggunakan Eutetik Mixture Local Anaestesi (EMLA)

Pengobatan tradisional Cina sudah ada sejak 3000 tahun yang lalu berdasarkan adanya aliran Energy yang mengalir sepanjang garis meridian ditubuh yang disebut $Q i$. Beberapa teknik pengobatan menggunakan titik tertentu ditubuh nyang disebut Accupoint. Banyak teknik yang digunakan untuk memanipulasi titik Accupoint di antaranya menggunakan jarum (Accupuncture) dan menekan titik Accupoint (Accupressure) (Frandsen., 2016).

Penggunaan titik akupunktur atau akupressure merupakan metode yang sudah digunakan, terutama di Cina dalam mengobati berbagai kondisi masalah kesehatan seperti nyeri kepala, beberapa titik akupoint dapat digunakan untuk penyembuhan, di antaranya adalah titik point FengFu atau GV 16. Fengfu GV 16 sendiri paling sering digunakan untuk pengobatan gangguan yang disebabkan oleh faktor eksogen, seperti flu biasa, sakit leher, sakit kepala, epilepsi, mania, pusing, nyeri tenggorokan , masalah pada kaki, dll. (Zhao JY, Liu Y, Xi SH, 2015).

JaeWoo Song et.al (2016), melakukan penelitian acak terkendali terkait manfaat terapi es batu dalam mengurangi nyeri saat dilakukan lokal anestesi pada 50 orang sampel yang terdiri dari dua grup dengan hasil bahwa terdapat penurunan nyeri yang signifikan $(\mathrm{p}=<0.001)$ pada kelompok perlakuan dibanding kelompok kontrol. Demikian pula Adel Alsantali (2018) yang melakukan Penelitian prospektif terhadap 23 pasien yang menjalani injeksi Botox pada telapak tangan, mendapatkan hasil yang signifikan $(\mathrm{p}<0.05)$ terhadap penurunan nyeri dengan melakukan kompres es dibanding dengan menggunakan Eutetik Mixture Local Anaestesi (EMLA) 
Pengobatan tradisional Cina sudah ada sejak 3000 tahun yang lalu berdasarkan adanya aliran Energy yang mengalir sepanjang garis meridian ditubuh yang disebut $Q i$. Beberapa teknik pengobatan menggunakan titik tertentu ditubuh nyang disebut Accupoint. Banyak teknik yang digunakan untuk memanipulasi titik Accupoint di antaranya menggunakan jarum (Accupuncture) dan menekan titik Accupoint (Accupressure) (Frandsen., 2016).

Penggunaan titik akupunktur atau akupresur merupakan metode yang sudah digunakan, terutama di Cina dalam mengobati berbagai kondisi masalah kesehatan seperti nyeri kepala, beberapa titik akupoint dapat digunakan untuk penyembuhan, di antaranya adalah titik point Feng Fu atau GV 16. Fengfu GV 16 sendiri paling sering digunakan untuk pengobatan gangguan yang disebabkan oleh faktor eksogen, seperti flu biasa, sakit leher, sakit kepala, epilepsi, mania, pusing, nyeri tenggorokan , masalah pada kaki, dll. (Zhao JY, Liu Y, Xi SH, 2015).

\section{KETERBATASAN PENELITIAN}

Peneliti masih mengalami keterbatasan seperti dalam mengontrol faktor-faktor yang mempengaruhi pengukuran suhu wajah dengan kamera thermal, seperti suhu kamar, posisi pasien saat pengambilan gambar, dan pergerakan dari pasien tersebut. Mengingat sensitivitas dari kamera thermal yang cukup tinggi, sehingga akan sangat mempengaruhi hasil dari pengukuran tersebut.

Jumlah sampel yang terbatas, baik dalam pemilihan maupun dalam pengumpulan data juga cukup terbatas termasuk jumlah perlakuan kepada setiap sampel yang hanya satu kali dilakukan intervensi, dikarenakan ratarata lama rawat yang singkat pada sampel sehingga peneliti tidak mendapatkan hasil maksimal dari perlakuan.

\section{KESIMPULAN DAN SARAN}

Pemberian es batu pada titik Feng Fu GV 16 tidak signifikan secara statistik menurunkan nyeri kepala pasca trauma pada pasien cedera kepala dengan indikator VRS. Pemberian es batu pada titik Feng Fu GV 16 tidak signifikan secara statistik menurunkan nyeri kepala pasca trauma pada pasien cedera kepala dengan indikator suhu wajah dengan monitoring kamera termal.
Bagi perawat khususnya di ruang rawat inap, dapat mengimplementasikan tindakan terapi es batu pada titik Feng Fu GV 16 untuk menurunkan nyeri kepala pada pasien cedera kepala ringan. Bagi penelitian selanjutnya agar dapat mengembangkan penelitian lanjutan dengan peranan efek es batu pada titik Feng Fu GV 16 dalam menurunkan nyeri dengan menggunakan instrumen yang lebih sensitif dan spesifik dengan mengendalikan faktor-faktor yang dapat mempengaruhi hasil pengukuran.

\section{DAFTAR PUSTAKA}

Andrews, S., \& Dempsey, B. (2007). Acupressure \& reflexology for dummies. Canada: Wiley Publishing.

Ariawan, I. (1998). Besar dan metode sampel pada penelitian kesehatan. Jakarta: Jurusan Biostatistik dan Kependudukan Fakultas Kesehatan Masyarakat, Universitas Indonesia, tidak dipublikasi kan.

Bogduk, N., \& Govind, J. (2009). Cervicogenic headache : an assessment of the evidence on clinical diagnosis, invasive tests, and treatment. The Lancet Neurology, 8(10), 959-968. https://doi.org/ 10.1016/ S1474-4422(09)70209-1.

Cederberg, D., \& Siesjö, P. (2010). What has inflammation to do with traumatic brain injury? Childs Nerv Syst, 26, 221-226. https://doi.org/10.1007/s00381-0091029-x.

Conidi, F. X. (2016). Interventional Treatment for Post-traumatic Headache. Curr Pain Headache Rep, 20(40), 1-8. https://doi.org/ 10.1007/s11916-0160570-z.

Defrin, R. (2014). Chronic post-traumatic headache: clinical findings and possible mechanisms. Journal of Manual and Manipulative Therapy, 22(1), 36-43. https://doi.org/10.1179/2042618613Y.00 00000053.

Elliott, M. B., Oshinsky, M. L., Amenta, P. S., Awe, O. O., \& Jallo, J. I. (2012). Nociceptive neuropeptide increases and periorbital allodynia in a model of traumatic brain injury. Headache, 52(6), 966-984. https://doi.org/10.1111/j.15264610.2012.02160.x.Nociceptive.

Ellis, N. (1994). Acupuncture in Clinical Practice: A guide for health 
professionals. Hong Kong: Chapman \& Hall.

Erel, V. K., \& Özkan, H. S. (2017). Thermal camera as a pain monitor. Journal of Pain Research, 10: 2827-2832.

Etehadtavakol, M., \& Ng, E. Y. (2017). Potential of Thermography in Pain Diagnosing and Treatment Monitoring. Dalam E. Y. Ng, \& M. Etehadtavakol, Application of Infrared to Biomedical Sciences (hal. 19-32). Singapore: Springer.

Grove, S. K., Gray, J. R., \& Burns, N. (2015). Understanding nursing research: Building an evidence-based practice. St. Louis Missouri: Saunders Elsevier.

Headache Classification Committee of the International Headache Society (IHS). (2013). The International Classification of Headache Disorders , 3rd edition (beta version). Cephalalgia, 33(9), 629-808. https://doi.org/10.1177/03331024134856 58.

Huang, Q., Li, W., Li, N., Wang, J., Tan, G., Chen, L., ... Zhou, J. (2013). Elevated blood pressure and analgesic overuse in chronic daily headache: an outpatient clinic-based study from Cina. The Journal of Headache and Pain, 14(1), 51. https://doi.org/10.1186/1129-237714-51

Hsieh, L.L., Liou, H., Lee, L., Chen, T. H., \& Yen, A.M. (2010). Effect of acupressure and trigger points in treating headache: A Randomized Controlled Trial. The American Journal of Chinese Medicine 38 (1), 1-14.

Kemenkes RI. (2014). Panduan akupresur mandiri bagi pekerja di tempat kerja. Kementerian Kesehatan Republik Indonesia 2015. Jakarta.

Khan, M. A., Asif, M., Rajput, H. I., Mughal, M. A., Aftab, K., Riaz, M., \& Chughtai, B. (2017). Effects of acupressure \& TENS along with hot pack in neck pain. Journal of Physical Fitness, Medicine \& Treatment in Sport (JPFMTS), 1(1), 1-5.

Kjeldgaard, D., Forchhammer, H. B., Teasdale, T. W., \& Jensen, R. H. (2014). Cognitive behavioural treatment for the chronic post-traumatic headache patient: a randomized controlled trial. The Journal of Headache and Pain, 15(1), 81. https://doi.org/10.1186/1129-2377-15-81
Kozier, B. (2010). Buku Ajar Fonddamental Keperawatan. Jakarta: EGC.

Lucas, S., Hoffman, J. M., Bell, K. R., \& Dikmen, S. (2014). A prospective study of prevalence and characterization of headache following mild traumatic brain injury. Cephalalgia, 34(2), 93-102. https://doi.org/10.1177/03331024134996 45.

Lucas, S., Hoffman, J. M., Bell, K. R., Walker, W., \& Dikmen, S. (2012). Characterization of headache after traumatic brain injury. Cephalalgia, 32(8), 600-606. https://doi.org/ $10.1177 / 0333102412445224$.

Mayer, C. L., Huber, B. R., \& Elaine Peskind. (2014). Traumatic Brain Injury, Neuroinflammation, and Post-Traumatic Head aches. Headache, 53(9), 15231530. https://doi.org/ 10.1111/ head. 12173. Traumatic.

Tamsuri, A. (2013). Konsep dan penatalaksanaan nyeri. Jakarta: EGC.

Packard, R. C. (2002). The Relationship of Neck Injury and Post-traumatic Headache. Current Pain and Headache Reports, 6, 301-307. https://doi.org/ 10.1007/s11916-002-0051-4.

Peterson, S. J., \& Bredow, T. S. (2013). Middle Range Theories. Application to nursing research.

Potter, P., \& Perry. (2010). Fundamental Keperawatan, Volume 1, Edisi 4. Jakarta: Penerbit Buku Kedokteran EGC.

Robinson, N. G. (2016). Interactive Medical Acupuncture Anatomy. Danvers: Teton NewMedia.

Satyanegara, Z. A. (2014). Ilmu Bedah Saraf Satyanegara Edisi $V$. Jakarta: PT Gramedia Pustaka Utama.

Seifert, T. D., \& Evans, R. W. (2010). Posttraumatic Headache: A Review. Curr Pain Headache Rep, 14, 292-298. https://doi.org/ 10.1007/s11916-0100117-7.

Sivak, S., Nosal, V., Bittsansky, M., Dluha, J., Dobrota, D., \& Kurca, E. (2016). Type and occurrence of serious complications in patients after mild traumatic brain injury. Bratisl Med J, 117(1), 22-25. https://doi.org/10.4149/BLL.

Sherwood, Lauralee. (2014). Fisiologi Manusia Dari Sel Ke Sistem, Edisi 8. Jakarta: EGC. 
Smith, M. J., \& Liehr, P. R. (2014). Middle range theory for nursing (Third). New York: Springer Publising Company.

Sprous-Blum, A. S., Gabriel, A. K., Brown, J. P., \& Yee, M. H. (2013). Randomized Controlled Trial : Targeted Neck Cooling in the Treatment of the Migrain Patient. Hawai Journal Of Medicine \& Public Health, July 2013, Vol 72, NO $7,237$.

Sugiono. (2016). Metode Penelitian Kuantitas, Kualitatif, dan $R \quad \& \quad D$. Bandung: Alfabeta.
Trevena, L., \& Cameron, I. (2011). Traumatic brain injury Long term care of patients in general practice, $40(12)$.

Wilson, L., \& Kolcaba, K. (2004). Practical application of comfort theory in the perianesthesia setting. Journal of Perianesthesia Nursing, 19(3), 164-173. https://doi.org/10.1016/j.jopan.2004.03.0 06

Zhao JY, Liu Y, Xi SH, X. N. (2015). Cinical Application regularity of FengFu (GV 16) acupoint: research on ancient Chinese Medical Literatur, 40(2), 170-3. 